\title{
Small-Scale Retailers in an Island Town
}

\author{
Sivapalan Selvadurai ${ }^{1}$, A. C. Er ${ }^{1}$, N. Lyndon ${ }^{1}$, A. Buang ${ }^{1}$, M. J. Mohd. Fuad ${ }^{1}$, A. Habibah ${ }^{1}$, J. Hamzah ${ }^{1}$, A. M. \\ Azima $^{1}$, A. B. Junaidi ${ }^{1} \&$ Mohd Yusof Hussein \\ ${ }^{1}$ School of Social, Development and Environmental Studies, Faculty of Social Sciences and Humanities, \\ University Kebangsaan Malaysia, Bangi, Malaysia \\ Correspondence: Sivapalan Selvadurai, School of Social, Development and Environmental Studies, Faculty of \\ Social Sciences and Humanities, Universiti Kebangsaan Malaysia, 43600 Bangi, Malaysia. Tel: 60-13-3524692. \\ E-mail:sivap02@gmail.com
}

\author{
Received: July 22, 2013 Accepted: September 1, 2013 Online Published: October 11, 2013 \\ doi:10.5539/ass.v9n14p86 \\ URL: http://dx.doi.org/10.5539/ass.v9n14p86
}

\begin{abstract}
This paper examines the competition faced by small-scale general store and textile retailing in an island town in Malaysia. The study was carried out in Labuan Town in Labuan Island of East Malaysia. A qualitative research design was utilized, involving primarily interview data which were collected from 12 in-depth interviews with 6 sundry and general store retailers and 6 textile retailers. Content analysis was executed to analyse the narrative data. The findings reveal that large store retailing negatively impact the small traders on trade diversion, but also positively modernize their retail formats. Competition was intense for the town centre small-scale retailers who were facing multiple competitions from large retailers and bazaar retailers in the town centre, small-scale retailers from the rural areas, as well as place competition in the region. The study suggests the need for creative response of the local authority in place making and balanced development, coupled with the strategic response of small-scale retailers in cultivating local enterprise.
\end{abstract}

Keywords: small-scale retailers, competition, sustainability, island economy, retail impacts

\section{Introduction}

Ecological complex is comprised of the interaction of population, organization, and technology in response to the environment (Duncan, 1964 in Grove \& Burch, 1997). As the population are diverse and complex it will of interest to see the positioning of retail organization. Retail organizations consist of both large and small-scale retailers, and both respond to the environment at both local and wider regional level at different technological capabilities. Competition is a key mechanism for explaining the organization of economic functions and the spatial distribution of human populations and services. The competitive environment of small-scale retailers entails the direct and indirect effect of competitors such as large-scale retailers, small-scale retailers alike and other informal operators. Though competition is often viewed as healthy in sustaining optimum price, consumer services, efficiency and others, it has been found that in some instances the liberal market forces can create monopolistic conditions detrimental to the small operators, who are often the backbone of most industrial sectors. The reason for the focus on competitive environment is because the entry of large-scale retailers is bound to have ramifications to the retail environment either directly or indirectly. Since retailers are a product of adaptation to economic ecological factors, it will be of interest to see the contextual influence of island towns. Labuan Island has a long history of trade experience, and as such the relationship of retail organizations on the island is of interest in view of the enabling and constraining features of the island economy. Besides that, an island is also porous and accessible via waterways depending on its juxtaposition of trade routes and regional population flows.

The literature on retail competition faced by small-scale retailers can be viewed from the impacts of large retail stores, impact of retail centres and impact of development policies. Large store retailing refers to large retail structures like hypermarkets, supermarkets, superstores, department stores and discount stores that reflect particular forms of specialization and division of labour and forms of organisation. This can vary in terms of their size, nature and the kinds of merchandise and services they provide (Neven et al., 2006). Several studies have emphasised the impact of large store retailing and shopping centres on independent retailing, particularly on small shops in urban areas (Shaw, 1987), including studies of market towns in the UK (Davies \& Kirby, 1983; Thomas \& Bromley, 2003), traditional shopping districts in Toronto, Canada (Shaw, 1987: 364) and city centres 
as in Sheffield (William, 1991). Studies have also been undertaken on the impacts of large stores on small-scale retailers in various types of trade: grocery retailers (Clarke, 2000), toy retailers (Thorpe, 1977) and retail pharmacies (Davies \& Kirby, 1983). These impact studies tend to come to similar conclusion that is the positive impact of large stores which have relatively few adverse effects on small independent shops and on localised retail areas. Some even lament at restrictions on large stores as counter-productive, in that it prevents positive spill-over effects to small stores (Boylaud \& Nicoletti, 2001). Additionally, only few shop closures were accounted from the new development of large stores (Davies \& Kirby, 1983). Some of the positive impacts of large-scale retailing are in terms of reasonable and lower prices (Thorpe, 1977), wider choice of goods (Sinha et al., 2005; Gilmour \& Gale, 2002), facilitating one stop shopping, self-service formats, which are all suited to urban communities that experience social change and values. These changes have also led to small-scale retailers adopting modern formats and moving into prime locations, with better design, product mix, package sizes with flexible stores in mind (Vastine 1991). These trends are currently emerging in developing countries like Malaysia.

However, there are few studies in the West that capture the negative consequences of large-scale retailing on smaller retailers (Clarke, 2000). Brennan and Lundsten (2000) discovered that the opening of large-scale retailing such as discount stores had negative consequence to the small-scale retailers. In a similar vein, Peterson and McGee (2000) in their study in five towns in Nebraska and Kansas found that smaller retail businesses experienced greater negative impact as a result of the opening of Wal-Mart. This situation was attributed to the trade diversion where customers were diverted away from existing smaller stores, favouring market dominance of the large-scale retailers who offer lower prices and large varieties of goods. However, Suryadarma et al. (2007) found mixed results on the impact of supermarket on small stores in Indonesia, where only the decline of middle-income customers were visibly felt. A local study carried out by Ahmad et al. (2008) on the perception of small-scale retailers on the entry of large retailing in Bandar Bukit Tinggi (Klang, Selangor) revealed that the majority of these small-scale retailers perceived facing stiff competition, encountering problems and reduction in customer patronage. The social polarization effect of large-scale retailing on small and traditional retailing can be viewed in terms of local cultural resources, not only in selling indigenous products (Dunne et al., 2011) but also in sustaining loyalty and social ties (Noble et al., 2006).

The emergence of out-of town large-scale retailing or suburban retailing was found to have an indirect competitive effect on the vitality and viability of town centre retailing which basically houses the majority of small-scale retailing. These out-of town centres were found to impact the small-store retailing in UK negatively (Fernie, 1997; Thomas \& Bromley, 2003; Arnold \& Luthra, 2000; Noble et al., 2006). The negative effects are seen in terms of reduction in passing customers and shrinking market share amongst small-scale retailers in the town centre (Smith \& Sparks, 2000). Similar experiences in Northern America were witnessed where the dominance of the retail landscape by WalMart was found in suburban locations (Hallsworth \& Evers, 2002; Peterson \& McGee, 2000), small towns (Collis et al., 2000) and even rural or non-metropolitan locations (Vias, 2004).

In addition to the impact of suburban large-scale retailing on small-scale retailing, the indirect role of development policies, especially piecemeal and ad hoc ones have impacted small-scale retailers differently (Porter, 1976). Studies on redevelopment policy of town centre by local authorities and its negative consequences to the small and traditional retailing have been well documented (Berry, 1978, Guy, 2002.). Policies sensitive to the sustainability of retail structure predominated by small-scale retailing has led to restriction and barriers to entry of large retailers. Some authors have recommended a balanced development approach in formulating commercial planning policy (Clarke, 2000) whilst some have suggested a wider partnership with key stakeholders (Collis et al., 2000).

In examining the competition faced by small-scale retailers in an island economy, an economic -ecological approach offers a broad view. Manzardo (1977) argued that trading groups such as retailers are a product of certain adaptation to ecological factors in the area in which the group is trying to survive (Shrader, 1994: 35). The range of resources available limits the traders' ability to produce adequate subsistence but the possibility of seeking additional income from outside source is available. Trade is possible where economic differential exists, together with distinct markets and a network of routes connecting them, which can extend beyond the local boundaries (Rees, 1992). Thus, in a small island economy such as in Labuan island, one can view the organizational relationship to the environment, which is different from mainland towns and cities(Calderwood \& Freathy, 2011). Small islands are often confronted with the character of dependency on external sources of growth (Petersen, 2003; Kapur, 2003), a key structural feature in their development process. The island's dependence includes development capital (i.e., central government assistance and initiatives), consumer markets (i.e., tourist market) and economic investment (Selvadurai et al., 2011). Small islands are often characterized by 
smallness, isolation, disadvantage in capital and population, high costs and problems of inaccessibility. According to Baldacchino (2002), the smallness and insularity of island characteristics has led to the lack of economies of scale, viable markets, labour power and expertise, and business know-how. The structural drawback that confronts island communities is often capitalised by external political structures to negotiate terms, which are often non-reciprocal, at the expense of the local interest. All is not gloomy though, as aside from these ecological constraints, island economies and towns are also opportune by the open border and fluid nature of islands that has enabled historical trade routes, prospective tourist resource ventures (i.e., island attraction, water sports) as well as illegal activities (i.e., smuggling trade) (Selvadurai et al., 2011). Hence, are there alternative resources that island economies offer that retailers can capitalize? Additionally, by examining the competitive environment of the small-scale retailers, we can examine the extent to which large-scale retailers have impacted them or whether the real competition is amongst the small-scale retailers themselves. Can small-scale retailing sustain itself in its existing form or can it adapt to the changing competitive environment? In general, this paper addresses the issue of sustainability of small-scale retailing amidst the impact of large-scale retailing and its ramifications to other retailers. Labuan as an island economy with dramatic urban restructuring provides an excellent site for the research. Specifically, the aim of this paper is to examine the competition faced by small store retailers in an island town.

\section{Study Area and Methods}

\subsection{Site Description}

The study was carried out in Labuan town which is located on Labuan Island off the coast of the state of Sabah in East Malaysia. Labuan Island has undergone several changes in its structure of governance, from the colonial occupation to provincial state government (i.e., Sabah) and finally under the Federal Government rule (i.e., Federal Territory). Changes in governance have led to changes in economic representation from a barter trade post in the 1970s to a service sector, followed by manufacturing sector free port status in 1984 and as an International Offshore Financial Centre (IOFC) status in 1990. However, the economic structure of the island is dominated by the public service employment and the wholesale, retail, hotel and restaurant sector. To complement the financial business, the government has been promoting business and shopping as tourist attraction. The Labuan island population stood at an estimated total of 85000 people in 2009, with 54752 people residing in Labuan town (GeoName, 2011).

Labuan offers a good ecological relationship in the nature of small island economic development. The Federal Government governs Labuan Island. The island is surrounded by provincial domestic markets and the regional East ASEAN market. Federal support and Labuan's position in the growing regional economy means the island is well positioned in a rapidly growing national economy. The Federal influence over regulatory mechanisms in the island is primarily in terms of incentives, and the current technological transaction innovation appears to garner sufficient ground for gradual development in the financial sector. The Federal Government is committed to developing the island as an offshore financial centre. This means aid or rent income is assured at this moment, thus reflecting the inflow of public investment in major infrastructural projects aimed at developing Labuan. The problem is not the commitment by investors (i.e. inflow of capital) but fulfilling the diverse community needs (i.e. interest groups), and the potential effects of these investments. Some policies are not favourable to the diverse interest groups in the island economy, amidst liberalization and marketization process infiltrating the neighbouring states. Policies that are favourable to trading and tourism in Labuan have witnessed the emergence of regional competitors.

Some of the challenges that Labuan has to contend with are its favourable shopping and tourism identity which is coming under threat from neighbouring Sarawak and Sabah that offer favourable pricing as a consequence of reduction of general tariff at the national level. Besides that, these regional competitors serve as attractive alternative tourist destinations. In 1987, the declaration of Langkawi Island (in Peninsular Malaysia) as a duty free port further dampens Labuan's comparative advantage. Other inherent challenges include the difficulty of access to the island economy in terms of distance and convenient mode of transport, as well increased cost of travel and freight cost for securing goods. The dependence on external supplies and services entail cost factors that disadvantaged the island economy due to its small market (Calderwood \& Freathy, 2011). This market constraint also inhibits the retail expansion prospects among the retailers.

The study was carried out in the commercial area of Labuan town located in Labuan Island off the coast of Sabah in East Malaysia. Most of the retail commercial activities are carried out in the town centre location, together with a few clusters of commercial land use in the suburban location (see Figure 1). The remaining retail outlets are scattered among the rural villages on the island. 


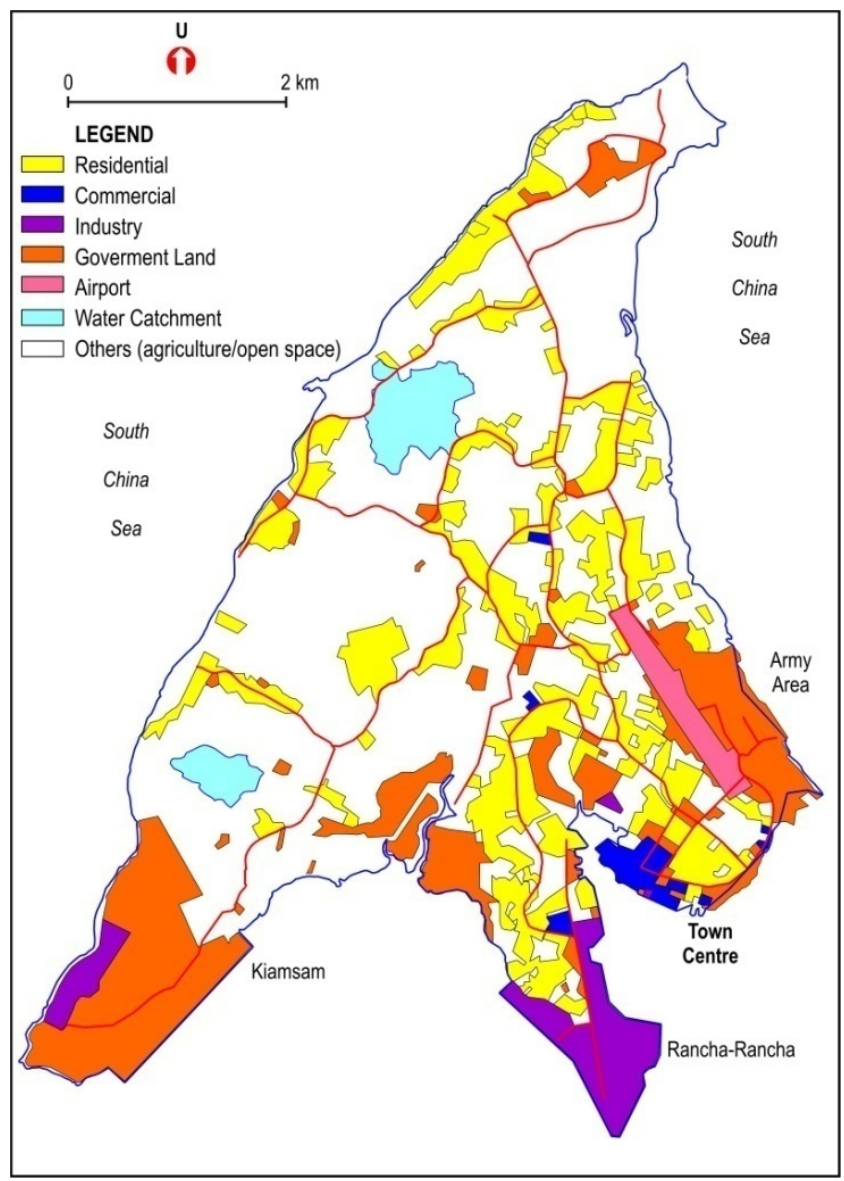

Figure 1. Land use map indicating the commercial area where retail activities occur

\subsection{Data Collection and Analysis}

A qualitative research design was utilized and data were collected from a series of recursive in-depth interview exercise (Khairul, 2008) with small-scale retailers conducted since 1997, with follow up interviews conducted in 2003 and 2005. The small-scale retailers can be based typically on either the firm's number of employees or annual sales and/or being independently owned (Robinson \& Pearce, 1984). However, in view of the lack of consensus on the definition of employees and annual sales (Keats \& Bracker, 1988), for the purposes of this article the notion of independently owned and operated and number of employees below 10 was used, as it reflects the impact of the owner on the organization and the scale of business in comparison to large-scale retailing. The sundry and general store trade and the textile trade were chosen as representing the small-scale retailers because they were the two major retail trades in Labuan town. As part of the main source of data, a total of 12 in-depth interviews with six sundry and general store retailers and six textile retailers were obtained. Interview data on the competition faced by the sundry and general stores and textile stores were focused on the impact of large-scale retailing and the inter-rivalry between the traders. The consequent sustainability of these small-scale retailing was subsequently addressed. Besides that, key informant interviews with wholesale traders, barter traders and supermarket operators were also carried out to supplement and to allow cross-reference of additional data. Narrative data were analyzed thematically (Novel et al., 2011) by examining the types of competition, impacts, as well as elicit appropriate reasons for competitive stances faced by the sundry and general retailers and textile retailers.

\section{Findings and Discussion}

\subsection{Competition between the Large and Small-scale Stores}

Prior to the declaration of Labuan as an IOFC, most retailing was small-scale. Competition among the general stores and textile stores was primarily between the medium and small-scale operation As such, the competition within the general store and textile retail trades before 1990 was between, on the one hand, those 'multi-traders who were engaged in the wholesale barter - trade' and, on the other hand, the small-scale retailers. The 
competition between these traders was mainly in the area of pricing and customer markets which favoured the multi-traders. In contrast, the small-scale general store and textile retailers were purchasing smaller quantities, incurring higher prices per unit, which translated into higher prices for the products. Besides that, the medium-scale retailers in these sectors were dependent not only on the local and tourist markets, but were also engaged in barter trade with the Filipinos, thus enjoying a comparative advantage in terms of broader market competition. In comparison, the small-scale general store and textile retailers were primarily dependent on the tourist and local market.

After 1991, Labuan witnessed an increase in the number of large variety store retailing in the form of supermarkets. Five large variety stores opened in the 1990s, and later four large variety stores and department stores in the early 2000s, intensifying the competition amongst the general store and ready-made clothing retailers who were dealing in a similar range of goods. The competition between the large variety stores in the grocery sub-trade was reflected by the price war in food products. For example, as remarked by a local-based wholesaler "some of the big players like ' $M$ large retailer' sell at cost price... for example for a 24-pack of canned drinks they sell for RM[Ringgit Malaysia]24". The wholesaler sold the same product at RM26 to other retailers. Thus, a price war existed because "big players" such as 'KE' wholesaler and ' $\mathrm{M}$ ' large retailer were selling at lower prices because they purchased at higher volume, and often when the competition intensified they undercut each other in these circumstances.

The impact of large stores on smaller stores can be clearly seen among the general stores, and somewhat less prominently in the textile trade. Prior to 1990, there were no major grocery stores, except for a few wholesale-retailers, but the grocery retailing scene changed after that period. Not only did the competition in certain ranges of food products increase amongst the larger food retailers, but the consequences of the "price war" had also negatively affected the small-scale retailers. The small-scale general store retailers subsequently experienced lower sales as a result of 'customer divergence' to larger stores, which have "high volume-lower cost" advantage at their disposal. Besides the low volume purchase, small traders buy through intermediaries such as distributors, receive fewer discounts and are forced to sell at higher prices, thus resulting in them losing their competitive stance.

The following case gives a glimpse of how the smaller retailers perceive the impact of one large superstore that was opened in 1997. ' $P R$ ' is a large store with a grocery supermarket and department store concept, focussing more on the grocery items. Its department store offers a range of ready-made clothes, mostly unbranded items as it is targeted at the middle and lower classes, depicting a mass marketing approach. The grocery section in this store offers a range of products sold at low cost. There are nearly 2000 items offered in this store. Pricing of goods implies a competitive stance in some strategic products. For example, the price of a can of coke in this large store was RM1, whereas the equivalent in other general store was about RM 1.50. But other items like Milo chocolate powder and Lindt chocolate was more expensive at ' $P R$ ' during the initial promotion period in comparison to other large stores in Labuan. As such, some of the smaller retailers argued that this large store offered lower prices for certain selected items, in comparison with other stores. Other retailers suggest that such a "price war" (i.e. lower price) strategy was merely an 'initial gimmick' to attract customers and that the prices will eventually stabilise or rise to the market price.

Informal interviews with some of the traders and wholesalers indicate diverse views on the competitive stance of this new large store. Some traders argue that since this large store purchases some goods from the local wholesalers, the prices of these goods are not going to vary that much in the market place. Some retailers suggest that this large store has an edge in terms of the variety of goods offered, and that other stores will have difficulty in matching or competing. Others argue that this large store has an advantage in its symbolic, leisure and psychological experience for the sheer size and ambience of its shopping environment. The cultural 'spectacle' environment suits the consumer lifestyle of the middle and younger age-groups. In addition, as a consequence of the dual-income and increasing number of women workforce, the emergence of these time-constrained customers is more likely to result in consumers who seek a one-stop experience that large retailing environment provides.

The attractive feature of supermarkets in terms of pricing, product choice-variety and ambiance and its negative consequence of trade diversion in which customers are drawn away from small-scale retailers are similar to what the literature has speculated (Brennan \& Lundsten, 2000; Vastine, 1991). Even if the supermarkets are located at inconvenient and distant locations, customers are likely to travel to such places. In this connection, the smaller general store retailers indicated that their previous customer profile had a broad mix of lower class (i.e. migrant workers and rural customer market) and middle class customers. Thus, the spread of supermarkets and the decline in the migrant worker market after 2000 had left the general store retailers with a shrinking market. This 
decline was as a result of the completion of major infrastructural projects in Labuan, of which migrant workers were heavily utilized and were further subjected to stringent control measures by the immigration authorities. Hence, there is a need for small-scale retailers to re-evaluate their market niches, product assortments and pricing strategies to circumvent their disadvantaged position (Andersen, 1997: 6).

The impact of supermarkets not only affects other retail stores (small and large) but also customers in terms of shopping habits, expectations, and identities, resulting in changes in perceptions and behaviour amongst them. Consequently, they have a double-effect on other retailers by creating trade market competition and by reducing the market share of their competitors, as well as changing the retailers' formats of retail provision, especially in terms of presentation, organization, self-service and attraction. Therefore, the prevalence of mini-market general stores utilizing the self-service concept is an outcome of the response to the changing customer expectations, particularly amongst the middle class customers. This finding coheres with the literature which suggests the positive effect of large retailing on small-scale retailers in terms of transfer of retail formats such as self-service and modernizing influence on traditional sundry general stores and textile stores (Vastine, 1991).

In addition to the direct and indirect impact of large stores (notably supermarkets) on general stores, these large entities have also had an effect on the smaller textile trade, though this has been somewhat different in magnitude, as a result of the different product postures. Unlike the general stores which trade in a wider range of products, the textile stores tend to specialise in particular target markets (such as children's wear, women's wear, etc.) under the broad categories of textile fabrics, ready-made clothing or sportswear. As such, the competitive situation was less pronounced as the marketing postures of these small textile stores were somewhat different. The smaller textile stores were engaged in different product provision in terms of value, brand, or product range. Competition was more prevalent among the speciality stores themselves.

\subsection{Competition amongst the Smaller Retailers}

In addition to competition between large and small-scale retailers, there was also competition amongst the small-scale retailers. The continued presence of many small-scale retailers in the two selected retail trades since the early 1990s depicts the confidence associated with the development of the IOFC and the Federal Government's commitment to develop the island economy. This was alluded to in the market and development discourse link. There is a perception amongst the retailers in the island that the historical constitution of the state developmental policies and efforts, coupled with private investment in the local economy are the generators of local economic and commercial development. This developmental discourse is tied in with the creation of demand for retail goods. This development-market link was given prominence in the narratives of local development, where retailers cited "the early 1980s" as associated with the industrial development in the local economy. During that period, the Sabah state government was developing the island as an industrial base, which was viewed by a mini-market retailer as "expanding jobs and population" as well as a phase for "recognising the market needs". This "developmental" narrative gives the impression of an active economic climate conducive to retail enterprise. Retailers expanded and diversified their stores strategically to capture the new market needs. Likewise, other retailers were similarly optimistic about perceived benefits from the development-market link when the island was declared as an IOFC (International Offshore Financial Centre) in 1990 with its concomitant development projects.

The continued presence of general store activity can be attributed to several reasons:

1) a common convention among aspiring entrepreneurs at the entry stage of business is to engage in general store retailing.

2) general store retailing is a convenient way of offering a mixed basket of goods capturing the variety of needs appropriate for a small customer market environment like Labuan.

3 ) the increase in general stores is attributed to the increase in more shop-lots becoming available in the 2000s, as well as optimism concerning development thereafter.

As a consequence of the increase in the number of small-scale general stores, intense competition was witnessed and these retailers were engaged in a "price game" where retailers try to reduce prices in certain products to attract customers. This "price game" was prevalent amongst the smaller retailers only and not the larger retailers, as the latter had an economic advantage as alluded to in the "price war' practice earlier.

Competition was pronounced in the general store trades, but was also important, though to a lesser extent, in the textile trade. A number of retailers responded by abandoning their previous trade or product line. The small-scale retailers foresee the competition from their large-scale counterpart, as well as new entrants who offer new and innovative products. The small-scale businesses and their product identities are positioned within a narrow or 
limited customer market share, thus losing their competitive stance with the larger counterparts. On the other hand, intense competition in re-pricing of goods and the sheer number of stores in the general store trade and to a lesser extent in the textile trade has prompted the traders to differentiate their product line. This differentiation of their product line created a value-added image for their product range as well as improved the physical outlook of the stores.

However, some general stores maintain the traditional format by serving a particular loyal clientele and provide personalized niche services and are thus able to remain in business. Small-scale retailers such as traditional sundry operators sell limited line of products and as such most of them source locally because of low volume. Local agents and wholesalers source goods from varying locations such as Singapore, Kuala Lumpur and China. Interestingly, they also source regional produce (such as Sabah and Sarawak products) through Kota Kinabalu (Sabah), for example, goods produced in Sabah such as food items like biscuits, noodles, toys, medicine etc. These small stores have strong survival capacities in view of their low overheads, and can adapt to changing taste and changing customer market segment such as the inflow of migrant workforce into Labuan. Thus, some small general stores were able to adapt and sustain by providing niche products (regional produce) and services, besides targeting changing customer flows such as migrant workers' needs. Not only can preservation of traditional shops be viewed as a critical part of the townscape heritage, but there are studies such as the one in Perthshire (Scotland) that has viewed the preservation of shop fronts as equally critical (Lennie \& Banfill, 2011). It would be of interest to examine the extent to which permanent shop houses which have been a part of the commercial townscape in small towns in Malaysia can be preserved via incentives through local authority urban management systems.

Even though some of the smaller general stores have adapted to the changing retail formats, there are others who are pessimistic about their future. Quite a number of traditional general stores have closed down and some are on the brink of closure. One of the consequences of the intense competition among the small-scale general stores has been the closure of shops. In the early 2000s, four general stores have closed down along the main street ('OKK Awang Road'), three along the secondary street ('Merdeka Road'), and one existing general store retailer on another secondary street ('Bunga Mawar Road') was contemplating of closing down his store. The closure of these stores was attributed to poor sales, as a result of their dependence on the low-end market segment that comprised primarily of the marginalised groups like the local rural populace and migrant workers, as well as the wider competition from the larger stores. Besides the changing customer market factor and slowdown in demand, increases in the cost of rented premises, utilised by most general store retailers, have led to high overheads. In fact, some of the owner-occupiers prefer to rent out their premise rather than to open general stores there because they can secure higher revenue through "better rent". One long-time retailer summed it up succinctly: "general store retailing is not suited to the current business environment because of small margins, high cost, and changing customer preference". These closures were mainly due to the competition from the opening of small sundries in the rural areas. Besides that, the entries of larger stores like supermarkets, which have primarily secured the middle class market as well as other classes who had previously patronised these smaller general stores, have also contributed to the closures.

The retailers attribute the decline to the substantial number of general stores springing up in the rural areas in the 2000s. One retailer remarked "last time there was not many general stores in rural areas, but now there are too many". Thus, the smaller general stores are confronted with double -competition, from the larger stores in the urban areas and from the rural general stores impinging on their previous market share. With low property rents and overheads in the rural areas and being served better by company agents and representatives, the rural retailers can secure goods at lower prices. As a consequence, the small traders in the urban areas encounter 'double competition' from the large retailers in the town centre location and its vicinity, whilst simultaneously the sprouting of small sundry stores in the rural locations has led to trade diversion away from them. Besides the competitive environment, rental hikes and slowdown in retail demand have also affected these smaller general stores.

Contrastingly, the competitive situation in the textile retail trade was somewhat different with varying forms of closure, adaptation and competition effects due to labour shortage, lack of customer demand, regional effect, and rivalry from intra-town centre bazaar trade. An illustration of a textile store that had experienced competition leading first to the partial abandonment of its product line and subsequently to closure is examined here. This firm 'K... Enterprise' commenced business in 1969 with the opening of a store dealing in barter trade and textile fabrics. It underwent expansion in the mid-1980s, opening a branch store along the main street dealing in sports clothing and apparel. However, due to intense competition in sporting goods, especially from the 'black market' through imitation of branded goods, its sales dropped dramatically and it was forced to close in 1995 . The 
retailer also claimed that labour shortage was one of the key factors for poor service and low sales, in addition to encountering "difficulty in maintaining business" amidst a slide in customer demand. Thus, the retailer focused on his fabric textile business in his main store, and had to close the sports branch store due to the intense competition and other related obstacles.

In the textile sector, many small outlets began trading not only in the permanent retail sector but also in the informal bazaar sector, where numerous stalls have been set up. The increased competition in the textile related retail trade could also be further subdivided into competition between traders engaged in textile-fabrics, readymade clothing and sportswear. However, the competition has become diffused with some traders having particular niches in specialist activities, like those with licensed branded products in the ready-made clothing, boutique stores and branded sports-wears sub-sectors. Price competition is somewhat balanced in these sub-sectors due to the retailers sourcing direct from their respective suppliers. Nevertheless, the textile trade has been confronted with increasing competition for customers. This is because the textile retail trade had initially expanded with the expectation of capturing the tourist market, but the shrinking tourist market experienced after 1993 and early 2000 has intensified competition amongst the small textile traders.

The literature in the West appears to suggest that there is less closure of small-scale retailers because they were able to adapt to the dynamics of the environment (Vastine, 1991). This situation might be true in conventional mainland areas. However, in Labuan's case pessimism looms because of the constraints and structural conditions of the island ecology. Fernie (1997) asserted that out of town or suburban large retailing impacted town centre's small stores, but in the case of Labuan Island, the urban areas are relatively small and as such the competition was from the concentration of large retailers within the town centre and its vicinity. As such, the spatial configuration is somewhat different in island economies. Besides that, a different feature in the island economy is the growth of rural small shops that have a negative effect on small general store retailing. Thus, in this modernizing island economy, the small traders of general stores in the town centre were confronted with large retailing threat from the town centre location and its vicinity and at the same time rural shop opening. In contrast, in the textile trade the competition were from the intra-town centre bazaar economy. Hence, there is a need for an organised town centre management to preserve the small shop sector particularly those in the traditional formats (Coca-Stefaniak et al. 2005).

\subsection{Place Competition Effects}

Retailers are likely to change their product line in response to changing customer markets. This was evident in the textile trade where a sizeable number of retailers who were previously involved in barter trade with the Philippines had concentrated on a range of 'palaikat' or sarong businesses. But in the 1990s, they shifted to other fabric-textile goods and readymade clothing, as a result of reduced demand from the Philippines trade and thus repositioned themselves in their attempt to target the tourist market. However, this shift in target marketing was short-lived when neighbouring regional tourist site attractions emerged together with large stores such as department stores in the mid-1990s. Neighbouring regions like Brunei, Sarawak and Sabah have been active in promoting alternative tourist destination sites. These sites have a comparative advantage in terms of on-land communication as opposed to Labuan's offshore site. Thus, this regional place competition has reduced the inflow of tourists to Labuan, thus dampening tourist demand on the local businesses.

The following case illustrates the experience of a textile store undergoing shifting demand as a consequence of place competition in the region. The ' $\mathrm{K}$. Textiles' is a textile store that was engaged in both retail and wholesale barter trading in the 1970s and 1980s, particularly in textile fabrics and "palaikat" (sarong) textile products with the Filipinos under the barter trade arrangement. After the decline in barter trade from 1985 onwards, this store had difficulty in sustaining its retail trade. According to the retailer "only the big stores can survive in wholesaling business.... the smaller stores can't survive". This implied that smaller retailers like himself had to shift their range of products from purely textile fabrics to a mix of fabrics and ready-made clothing in the 1990s, reflecting the changing textile customer market from a thriving barter trade with the Filipino market to an emerging regional tourist market. However, the tourist market was not sustainable in the mid 1990s and early 2000 when other regional site and place competition resulted in a decline in the inflow of tourists to Labuan. As this case illustrates, the textile trade was affected directly by the decline in barter trade with the Filipinos. Similarly, some of the product lines in the general stores were also affected by the decline in barter trade. Besides that, changes in the regional consumer market can be seen in the reduction of tourists from Brunei who used to be a significant market segment for local textile sales. Brunei's own introduction of "duty free status" and a premiere theme park offering free entry reduced the flow of tourists to Labuan. In fact, Brunei tourists' alternative shopping site has been Miri, which became accessible by land in the late 1990s and is convenient for family outings. Furthermore, wider reductions in national taxes for tourist consumable items aimed at encouraging domestic tourism have dampened 
retail sales in Labuan as neighbouring Sarawak and Sabah also now enjoy a comparative advantage. This has created place competition between different destinations in the region. Labuan is constrained by its geographical isolation and the difficulty of mobility to on-island sites, and has lost some of its attractiveness as a tourist destination. This is compounded by the lack of complementary and accessible tourist sites within Labuan, thus resulting in it losing its shopping tourist attractions to other tourist sites in the region, such as Kota Kinabalu and Sandakan in Sabah, Miri in Sarawak, and Bandar Seri Begawan in Brunei.

One of the interesting findings that can be drawn from the retail competition of small traders is that these firms are not only competing within the island economy, but are also subjected to competition from different places within the region. Porter (1990) extends the inter-firm competition to inter-place competition, extending his theory of the competitive advantage of firms to regions and urban districts. Thus, the competitive advantages of small firms are also dependent on the competitive advantage of the place or island within the region. As such, in the retail trade, not only is the idea of place ecology important but so too is the need to extend a locality's relative retail trade position in the regional ecology. In the Labuan experience, attempts to use creativity by way of attracting footloose capital in offshore finance and drawing on financial class migrants to this struggling place appear fruitless. Attempts to remedy this place by focusing on macro-scale projects need to shift to innovative place making measures (Gibson \& Klocker, 2005) in view of the competitions of localities within the region.

\section{Conclusion}

The small-scale retailers not only faced competition from the large-scale retailers and amongst the small-scale retailers themselves, but also place competition that has ramifications on their positioning and future operations. In comparison to mainland economies, the small-scale retailers in the island economy have a different economic ecological relationship in view of their dependent disadvantaged position.

Large-scale retailing was found to have negatively impacted small-scale retailers in terms of price, product choice and variety leading to trade diversion. On the positive side, small-scale retailers were adapting their retail format to modern structures introduced by the large retailers. Competition was intense for the town centre small-scale retailers who were facing multiple competitions from large retailers and bazaar retailers in the town centre, small-scale retailers from the rural areas, as well as place competition in the region. However, there were some small-scale retailers who were able to adapt and sustain the traditional structures for the migrant and rural customer market.

The urban economic ecology of the island was found to have different response to competition between the different trades. The general and sundry trade as compared to the textile trade was impacted negatively, though some were able to adapt creatively. Some of the small-scale retailers were able to actively adapt to change without eroding the resilience (Walker et al., 2004) of the traditional sector while others were vulnerable and consequently this led to closure.

There were several implications that can be drawn from this study. The creative role of the local authority in place making and balanced development coupled with the strategic response of small-scale retailers are critical in cultivating local enterprise. Though the entry of large retailing poses threat to small-scale retailers, a critical factor to their sustainability is the place making measures by the local authority. If they are not creative in constantly promoting and drawing capital for local development, then the small traders are in jeopardy. The local authority needs to control development of large retailers (Clarke, 2000) so as to ensure fair competition and sustain local enterprise, which will then ensure sustainability of the local and regional produce. Meanwhile, small-scale retailers have to adapt and find niche products based on new demands of the changing customer market, as well as look beyond the locality (Rees, 1992).

The island economy poses a different ecological and structural relationship to the retail traders. Its isolation from the mainland market can be juxtaposed with its fluid boundaries that enabled wider flow of people and goods. Islands can pose a constraining element, or it can provide strategic position and offer diverse options for economic function. The pessimism of the small retail traders was not solely due to the impact of the large-scale retailing but also their limited local consumer market where the development discourse of island economy was externally determined. This coheres with ecological constraint argument put forward by Shrader (1994). The structural constraint of future development as well as the limited customer market is a common feature of island economies that is dependent on externally induced development. A key feature of general retail business has been its ability to provide variety of goods with a focus on cultural and local goods that are unique. Thus, the ability of small-scale retailers to sustain their business by not only fulfilling the previous rural and suburban customer demand, but also the emergent migrant worker customer needs suggest its adaptability to changing structural conditions. Innovations by means of creative place making (i.e. branding) measures and town centre 
management by the local authority are a necessary ingredient for the sustainability of small traders.

\section{Acknowledgment}

The publication of this research finding is made possible by Universiti Kebangsaan Malaysia's Research Stimulus Grant ( UKM-DLP-2012-030) under the leadership of Associate Prof. Dr. Er Ah Choy.

\section{References}

Ahmad, A. H., Mohd Nor, S., Rahman, I. H. A., Moen, J. A., \& Che Wel, C. A. (2008). Small retailers and entrepreneurs' perceptions on the departmental store development: A Malaysian case study. International Review of Business Research Papers, 4(1), 1-10. Retrieved from http://www.bizresearchpapers.com/Paper-2new\%20(2).pdf

Andersen, A. (1997). Small store survival: success strategies for retailers. New York, USA: John Wiley.

Arnold, S. J., \& Luthra, M. N. (2000). Market entry effects of large format retailers: a stakeholder analysis. International Journal of Retail \& Distribution Management, 28(4/5), 139-154. http://dx.doi.org/10.1108/09590550010319896

Baldacchino, G. (2002). A taste of small-island success: a case from Prince Edward Island. Journal of Small Business Management, 40(3), 254-259. http://dx.doi.org/10.1111/1540-627X.00055

Berry, R. K. (1978). Public and private policies towards small shops. Corbridge, UK: Retailing and Planning Associates.

Boylaud, O., \& Nicoletti, G. (2001). Regulatory reform in retail distribution. Corbridge, UK: OECD Economic Studies No. 32, 2001. Retrieved from http://www.oecdpublishing.com/dataoecd/30/52/2732142.pdf

Brennan, D. P., \& Lundsten, L. (2000). Impacts of large discount stores on small US towns: reasons for shopping and retailer strategies. International Journal of Retail \& Distribution management, 28(4/5), 155-161. http://dx.doi.org/10.1108/09590550010319904

Calderwood, E., \& Freathy, P. (2011). Challenges in the supply of perishable products to island communities. The International Review of Retail, Distribution and Consumer Research, 21(2), 145-160. http://dx.doi.org/10.1080/09593969.2011.562679

Clarke, I. (2000). Retail power, competition and local consumer choice in the UK grocery sector. European Journal of Marketing, 34(8), 975-1002. http://dx.doi.org/10.1108/03090560010331469

Coca-Stefaniak, A., Hallsworth, A. G., Parker, C., Bainbridge, S., \& Yuste, R. (2005). Decline in the British small shop independent retail sector: exploring European parallels. Journal of Retailing and Consumer Services, 12(5), 357-371. http://dx.doi.org/10.1016/j.jretconser.2004.11.007

Collis, C., Berkeley, N., \& Fletcher, D. R. (2000). Retail decline and policy responses in district shopping centres. Town Planning Review, 71(2), 149-168. Retrieved from http://liverpool.metapress.com/content/t0m38m66hu759331

Davies, R. L., \& Kirby, D. (1983). Current research in UK distribution research. International Journal of Physical Distribution \& Logistics Management, 13(5/6), 68-92. http://dx.doi.org/10.1108/eb014566

Duncan, O. D. (1964). Social organization and the ecosystem. Handbook of modern sociology. New York, USA: Rand McNally.

Dunne, J. B., Chambers, K. J., Giombolini, K. J., \& Schlegel, S. A. (2011). What does 'local' mean in the grocery store? Multiplicity in food retailers' perspectives on sourcing and marketing local foods. Renewable Agriculture and Food Systems, 26, 46-59. http://dx.doi.org/10.1017/S1742170510000402

Fernie, J. (1997). Retail change and retail logistics in the UK: past trends and future prospects. The Industries Journal, 17(3), 383-396. http://dx.doi.org/ 10.1080/02642069700000025

GeoName. (2011). Bandar Labuan, GeoNames geographical database. Retrieved from http://www.geonames.org/maps/google_5.289_115.269.html

Gibson, C., \& Klocker, N. (2005). The 'cultural turn' in Australian regional economic development discourse: neoliberalising creativity? Geographical Research, 43, 93-102. http://dx.doi.org/10.1111/j.1745-5871.2005.00300.x

Gilmour, B., \& Gale, F. (2002). A maturing retail sector: wider channels for food imports? China's food and agriculture: issues for the 21st Century. Market and Trade Economics Division, Economic Research 
Service, U.S.Department of Agriculture. Agriculture Information Bulletin No. 775. Washington DC. Retrieved from http://ers.usda.gov/publications/aib775/aib775.pdf\#page $=20$

Grove, J. M., \& Burch Jr, W. R. (1997). A social ecology approach and applications of urban ecosystem and landscape analyses: a case study of Baltimore, Maryland. Urban Ecosystems, 1, 259-275. http://dx.doi.org/10.1023/A:1018591931544

Guy, C. (2002). Is retail planning policy effective? The case of very large store development in the UK. Planning Theory and Practice, 3(3), 319-330. http://dx.doi.org/10.1080/1464935022000019554

Hallsworth, A., \& Evers, D. (2002). The steady advance of Wal-Mart across Europe and changing government attitudes towards planning and competition. Environment and Planning C: Government and Policy, 20(2), 297-309. Retrieved from http://www.environmentandplanning.com/abstract.cgi?id=c20m

Kapur, D. (2003). Remittances: the new development mantra? G-24 Technical Group Meeting, Center for Global Development, Harvard University. Retrieved http://dspace.cigilibrary.org/jspui/bitstream/123456789/13268/1/Remittances\%20The\%20New\%20Develop ment\%20Mantra.pdf?1

Keats, B. W., \& Bracker, J. S. (1988). Toward a theory of small firm performance: A conceptual model. American Journal of Small Business, 12(4), 41-58. Retrieved from http://www.mendeley.com/research/toward-a-theory-of-small-firm-performance-a-conceptual-model

Khairul, B. M. N. (2008). Case study: A strategic research methodology. American Journal of Applied Sciences, 5(11), 1602-1604. http://dx.doi.org/10.3844/ajassp.2008.1602.1604

Lennie, L., \& Banfill, P. (2011). A heritage of shops; an investigation into the evolution of historic shopfronts in Perth and Perthshire. Retrieved from http://www.arct.cam.ac.uk/personal-page/james/ichs/Vol\%202\%201901-1920\%20Lennie.pdf

Manzardo, A. E. (1977). Ecological constraints on the trans-Himalayan trade in Nepal. Contributions to Nepalese Studies, $\quad 4(2), \quad 63-81 . \quad$ Retrieved from http://himalaya.socanth.cam.ac.uk/collections/journals/contributions/pdf/CNAS_04_02_03.pdf

Neven, D., Reardon, T., Chege, J., \& Wang, H. (2006). Supermarkets and consumers in Africa: The case of Nairobi, Kenya. Journal of International Food \& Agribusiness Marketing, 18(1-2), 103-123. http://dx.doi.org/10.1300/J047v18n01_06

Noble, S. M., Griffith, D. A., \& Adjei, M. T. (2006). Drivers of local merchant loyalty: Understanding the influence of gender and shopping motives. Journal of Retailing, 82(3), 177-188. http://dx.doi.org/10.1016/j.jretai.2006.05.002

Novel, L., Selvadurai, S., Er, A. C., Mohd Fuad, M. J., Zaidah, M., Aishah, M., \& Buang, A. (2011). Intangible factors influencing gender differences in educational attainment using an abductive research strategy. World Applied Science Journal, 13(Special Issue on Human Dimensions of Development), 46-52. http://idosi.org/wasj/wasj13(HDD)/9.pdf

Petersen, E. (2003).The catch in trading fishing access for foreign aid. Marine Policy, 27(3), 219-228. http://dx.doi.org/ 10.1016/S0308-597X(02)00059-3

Peterson, M., \& McGee, J. E. (2000). Survivors of "W-day": an assessment of the impact of Wal-Mart's invasion of small town retailing communities. International Journal of Retail \& Distribution Management, 28(4/5), 170-180. http://dx.doi.org/10.1108/09590550010319922

Porter, L. (1976). The retailer and policy -note 13. London, UK: TESCO.

Porter, M. E. (1990). The competitive advantage of nations. New York, USA: Free Press, MacMillan.

Rees, W. E. (1992). Ecological footprints and appropriated carrying capacity: what urban economics leaves out. Environment and Urbanization, 4(2), 121-130. http://dx.doi.org/10.1177/095624789200400212

Robinson, R. B., \& Pearce, J. A. (1984). Research thrusts in small firm strategic planning. Academy of Management Review, 9, 128-137. Retrieved from http://www.jstor.org/stable/258239

Selvadurai, S., Moorthy, R., Lyndon, N., \& Er, A. C. (2011). Persistence of traditional retailing in an island town. American Journal of Economic and Business Administration, 3(3), 450-455. http://dx.doi.org/10.3844/ajebasp.2011.450.455

Shaw, G. (1987). Institutional forces and retail change: a case study of metropolitan Toronto. Geoforum, 18(4), 
361-369. http://dx.doi.org/10.1016/0016-7185(87)90027-3

Shrader, H. (1994). The discussion of trade in social science. The moral economy of trade: Ethnicity and developing markets. London, UK: Routledge.

Sinha, P. K., Mathew, E., \& Kansal, A. (2005). Format choice of food and grocery retailer. Ahmedabad, India: Research and Publication. Indian Institute of Management. Retrieved from http://iimahd.ernet.in/assets/snippets/workingpaperpdf/2005-07-04pksinha.pdf

Smith A., \& Sparks, L. (2000).The independent small shop in Scotland: A discussion of roles and problems. Scottish Geographical Journal, 116(1), 41-58. http://dx.doi.org/10.1080/00369220018737078

Suryadarma, D., Poesoro, A., Budiyati, S., Akhmadi, \& Rosfadhila, M. (2007). Impact of supermarkets on traditional markets and retailers in Indonesia's urban centers. SMERU Research Report, The SMERU Research Institute, Jakarta. Retrieved from http://www.smeru.or.id/report/research/supermarket/supermarket_eng.pdf

Thomas, C. J., \& Bromley, R. D. F. (2003). Retail revitalization and small town centres: the contribution of shopping linkages. Applied Geography, 23, 47-71. http://dx.doi.org/10.1016/S0143-6228(02)00068-1

Thorpe, D. (1977). The independent toy retailer: a study of his characteristics and comments. Research Report 28. Manchester, UK: Retail Outlets Research Unit, Manchester Business School.

Vastine, W. J. (1991). The convenience store industry in the 1990s and beyond. International Journal of Retail \& Distribution Management, 19(6), 27-31. http://dx.doi.org/10.1108/EUM0000000002953

Vias, A. C. (2004). Bigger stores, more stores, or no stores: paths of retail restructuring in rural America. Journal of Rural Studies, 20(3), 303-318. http://dx.doi.org/10.1016/j.jrurstud.2003.10.003

Walker, B., Holling, C. S., Carpenter, S. R., \& Kinzig, A. (2004). Resilience, adaptability and transformability in social-ecological systems. Ecology and Society, 9(2), 5. Retrieved from http://www.ecologyandsociety.org/vol9/iss2/art5

William, J. J. (1991). Meadowhall: its impact on Sheffield city centre and Rotherham. International Journal of Retail \& Distribution Management, 19(1), 29-37. http://dx.doi.org/10.1108/EUM0000000002940

\section{Copyrights}

Copyright for this article is retained by the author(s), with first publication rights granted to the journal.

This is an open-access article distributed under the terms and conditions of the Creative Commons Attribution license (http://creativecommons.org/licenses/by/3.0/). 